\title{
CD1C Gene
}

National Cancer Institute

\section{Source}

National Cancer Institute. CD1C Gene. NCI Thesaurus. Code C118907.

This gene is involved in antigen presentation of lipids or glycolipid antigens. 